Review

\title{
Application of Iron Magnetic Nanoparticles in Protein Immobilization
}

\section{Jiakun Xu, Jingjing Sun, Yuejun Wang *, Jun Sheng, Fang Wang and Mi Sun *}

Key Laboratory of Sustainable Development of Marine Fisheries, Ministry of Agriculture,

Yellow Sea Fisheries Research Institute, Chinese Academy of Fishery Sciences, Qingdao 266071, China; E-Mails: chenfeng858652@163.com (J.X.); jingjingsuna@163.com (J.S.); shengjun@ysfri.ac.cn (J.S.); wendywf2002@163.com (F.W.)

* Authors to whom correspondence should be addressed; E-Mails: qwnw7156@sina.com (Y.W.); hhsunmi@yeah.net (M.S.); Tel.: +86-532-8581-9525 (M.S.).

Received: 23 May 2014; in revised form: 9 July 2014 / Accepted: 9 July 2014 /

Published: 4 August 2014

\begin{abstract}
Due to their properties such as superparamagnetism, high surface area, large surface-to-volume ratio, easy separation under external magnetic fields, iron magnetic nanoparticles have attracted much attention in the past few decades. Various modification methods have been developed to produce biocompatible magnetic nanoparticles for protein immobilization. This review provides an updated and integrated focus on the fabrication and characterization of suitable magnetic iron nanoparticle-based nano-active materials for protein immobilization.
\end{abstract}

Keywords: iron magnetic nanoparticles; surface modification; protein immobilization; application

\section{Introduction}

Enzyme-catalyzed reactions usually take place under relatively mild conditions, which make them ideal alternatives to various traditional chemical reactions. However, free enzymes usually have poor stability towards $\mathrm{pH}$, heat or other factors and are difficult to recover and reuse $[1,2]$. Therefore, there is a great demand for ways to improve enzyme stability and reusability.

Immobilization techniques, as a very powerful tool, have been intensively utilized to prepare various high-performance and economically-feasible biocatalysts with improved stability and 
resuability. By tuning the immobilization strategies and carefully selecting the materials, the immobilized enzymes can work in a much broader $\mathrm{pH}$ and temperature range and show higher thermal stability than the native ones, which could be attributed to multipoint, multi-subunit immobilization or generation of favorable environments. Several new types of carriers and technologies on immobilization have been developed in the recent past to enhance the loading, activity and stability of enzymes [3-10], which decrease the enzyme biocatalyst cost for industrial application. These include cross-linked enzyme aggregates [11-13], microwave-assisted immobilization [14], click chemistry technology [15], mesoporous supports [16] and most recently nanoparticle-based immobilization of enzymes [17-19].

Magnetic metal nanoparticles have been used in protein/enzyme immobilization owing to their unique properties such as superparamagnetism, high surface area, large surface-to-volume ratio, easy separation under external magnetic fields [20-24]. Another key factor to take full advantages of nanoparticles such as magnetic nanoparticles is how to ideally regulate the orientation of the proteins/enzymes on the supports. Compared to porous supports, such non-porous nanoparticles have no external diffusion problems, making them more competitive especially for large scale industrial usage in solid-liquid systems (e.g., precipitated protein). However, as drawbacks compared to porous supports, proteins/enzymes immobilized on non-porous nanoparticles may suffer inactivation for soluble proteins/enzymes, especially through interaction with gas bubbles generated by strong stirring or bubbling of oxygen [25]. Such inactivation by interfaces might proceed and finally result in the irreversible activity loss due to the sustained effects such as destabilization of electrostatic, hydrophobic and hydrogen bonds [26]. The frequently utilized magnetic nanoparticles are iron oxides, among which superparamagnetic $\mathrm{Fe}_{3} \mathrm{O}_{4}$ nanoparticles are the most prevalent materials because they have low toxicity, good biocompatibility [27-31]. Since the bare iron magnetic nanoparticles often have high reactivity and easily undergo degradation upon direct exposing to certain environment, leading to poor stability and dispersity [32,33]. Various modification methods have been developed to get the soluble and biocompatible iron magnetic nanoparticles for protein immobilization [34]. This review provides an updated and integrated focus on the fabrication and characterization of suitable iron magnetic nanoparticles for protein immobilization. In addition, the applications of immobilized enzymes based on iron magnetic nanoparticles in certain fields including immunoassay, biosensor, bioseparation, targeted drug delivery, and environmental analysis have also been summarized.

\section{Methods for Preparation of Magnetic Nanoparticles}

Magnetic nanoparticles can be synthesized by physical, chemical and biological methods: (i) physical methods [35-38], such as gas-phase deposition and electron beam lithography; (ii) wet chemical preparation methods, such as sol-gel synthesis [39,40], oxidation method [41,42], chemical coprecipitation [43,44], hydrothermal reactions [45,46], flow injection synthesis [47], electrochemical method [48,49], aerosol/vapor phase method [50,51], sonochemical decomposition reactions [52,53], supercritical fluid method [54,55], synthesis using nanoreactors [56,57] and (iii) microbial methods [58-60].

As shown in Table 1, each of the above mentioned methods have their own advantages and disadvantages. Although physical methods are easy to perform, it is rather difficult to control the 
particle size with them. In the case of wet chemical preparation methods, some of them yield efficient control of the particle size by carefully adjusting the involved parameters, such as sol-gel method, chemical coprecipitation, hydrothermal method, flow injection method, electrochemical method, sonochemical decomposition method, supercritical fluid method and synthesis using nanoreactors. In particular, chemical coprecipitation technique of iron salts in aqueous medium might be the simplest and most efficient pathway to obtain iron magnetic nanoparticles. It has been demonstrated the particle size as well as the polydispersity of the nanoparticles could be tailored by changing the associated factors such as $\mathrm{Fe}^{2+} / \mathrm{Fe}^{3+}$ ratio [43], base $\left(\mathrm{NaOH}\right.$, ammonium hydroxide, and $\left.\mathrm{CH}_{3} \mathrm{NH}_{2}\right)$ [61], ionic strength $\left(\mathrm{N}\left(\mathrm{CH}_{3}\right)^{4+}, \mathrm{CH}_{3} \mathrm{NH}^{3+}, \mathrm{NH}^{4+}, \mathrm{Na}^{+}, \mathrm{Li}^{+}\right.$and $\left.\mathrm{K}^{+}\right)$[62]. Some other apparently small factors also have an influence on the size of the nanoparticles [63]. For example, an increase of the mixing rate or temperature tends to decrease the particle size. Inlet of nitrogen into the reaction system not only protects against critical oxidation of the magnetite but also reduces the particle size when compared to methods without oxygen removal. Microbial methods ensure high yield, good reproducibility, and good scalability, as well as low cost, but the fementation process is rather time-consuming.

Table 1. Comparation between methods for synthesis of magnetic nanoparticles.

\begin{tabular}{|c|c|c|c|}
\hline \multicolumn{2}{|c|}{ Methods } & Advantages & Disadvantages \\
\hline \multirow[b]{2}{*}{ physical methods } & gas-phase deposition & easy to perform & $\begin{array}{l}\text { difficult to control } \\
\text { the particle size }\end{array}$ \\
\hline & electron beam lithography & $\begin{array}{l}\text { well controlled } \\
\text { inter-particle spacing }\end{array}$ & $\begin{array}{c}\text { expensive and } \\
\text { highly complex } \\
\text { machines requiring }\end{array}$ \\
\hline \multirow{10}{*}{$\begin{array}{l}\text { wet chemical } \\
\text { preparation methods }\end{array}$} & sol-gel synthesis & $\begin{array}{c}\text { precisely controlled in size, } \\
\text { aspect ratio, and internal } \\
\text { structure }\end{array}$ & $\begin{array}{c}\text { weak bonding, } \\
\text { low wear-resistance, } \\
\text { high permeability }\end{array}$ \\
\hline & oxidation method & $\begin{array}{l}\text { uniform size and narrow } \\
\text { size distribution }\end{array}$ & small-sized ferrite colloids \\
\hline & chemical coprecipitation & simple and efficient & $\begin{array}{c}\text { not suitable for } \\
\text { the preparation of } \\
\text { high pure, accurate } \\
\text { stoichiometric phase }\end{array}$ \\
\hline & hydrothermal reactions & $\begin{array}{l}\text { easy to control particle } \\
\text { size and shapes }\end{array}$ & $\begin{array}{l}\text { high reaction temperature, } \\
\text { high pressure }\end{array}$ \\
\hline & flow injection synthesis & $\begin{array}{l}\text { good reproducibility and } \\
\text { high mixing homogeneity } \\
\text { together with a precise } \\
\text { control of the process }\end{array}$ & $\begin{array}{c}\text { need continuous or } \\
\text { segmented mixing } \\
\text { of reagents under a laminar } \\
\text { flow regime in } \\
\text { a capillary reactor }\end{array}$ \\
\hline & electrochemical method & easy to control particle size & reproducibility \\
\hline & aerosol/vapor phase method & high yields & $\begin{array}{l}\text { extremely high } \\
\text { temperatures }\end{array}$ \\
\hline & $\begin{array}{c}\text { sonochemical } \\
\text { decomposition reactions }\end{array}$ & $\begin{array}{l}\text { narrow particle } \\
\text { size distribution }\end{array}$ & $\begin{array}{l}\text { mechanism not } \\
\text { still understood }\end{array}$ \\
\hline & supercritical fluid method & $\begin{array}{l}\text { efficient control of the } \\
\text { particle size, no organic } \\
\text { solvents involved }\end{array}$ & $\begin{array}{l}\text { critical pressure } \\
\text { and temperature }\end{array}$ \\
\hline & synthesis using nanoreactors & $\begin{array}{l}\text { the possibility to precisely } \\
\text { control the NP size }\end{array}$ & complex condition \\
\hline microbial methods & microbial incubation & $\begin{array}{l}\text { high yield, good } \\
\text { reproducibility, and good } \\
\text { scalability, low cost }\end{array}$ & time-consuming \\
\hline
\end{tabular}


To get the products with homogeneous composition and narrow size distribution, some purification procedure such as ultracentrifugation, size-exclusion chromatography are required.

\section{Modification of Iron Magnetic Nanoparticles}

Naked iron magnetic nanoparticles are generally unstable in strong acidic solutions and undergo leaching, which strongly limits the reusability and reduces the lifetime of such materials. The large ratio of surface area to volume brings in another limitation-aggregation of particles and thus a minimization in their surface energy ocurrs due to strong magnetic attractions between particles, limiting their dispersion in aqueous solutions and matrices. The exposition of the proteins/enzymes to such interfaces would result in the decrease or loss of the activity.

To overcome such limitations, various approaches are used to modify the surface via loading of other target chemicals or biological materials during or after the synthesis process. These techniques not only optimize the surface properties such as biocompatibility, dispersibility and biodegradability of iron magnetic nanoparticles, but also provide an environment for the transferring of hydrophobic iron oxide nanoparticles into a hydrophilic system.

Various materials have been involved in this process. Surfactants such as oleic acid, lauric acid, alkylsulphonic acids, and alkylphosphonic acids are common used molecules [64]. Several polymers such as polyethylene glycol (PEG), polyvinylpyrrolidone (PVP), poly(ethylene-co-vinyl acetate), poly(lactic-co-glycolic acid) (PLGA), and polyvinyl alcohol (PVA) have also been used as coating materials in aqueous suspension [65]. Moreover, natural dispersants including gelatin, dextran, polylactic acids, starch, albumin, liposomes, chitosan, ethyl cellulose have also been extensively employed for coating purpose in aqueous medium [66-69].

Surface silanization is undoubtedly the most widely used technique to introduce surface functional groups on bare magnetic nanoparticles due to its characteristics such as satisfying responsivity, low cytotoxicity, high stability under acidic conditions, inertness to redox reactions and easy to perform surface chemical modification. Furthermore, the reaction can be either carried out in aqueous media or organic solvents at moderate temperatures, and no particular conditions or expensive equipment are required, therefore, it is considered as an ideal method for the protection of the inner magnetic core. The reaction mechanism is schematically shown in Figure 1 [70]. Silane molecules are firstly activated (hydrolysed) and then followed by the condensation reactions occurring between the $\mathrm{Si}-\mathrm{OH}$ groups of the silanol and the $\mathrm{OH}$ groups of the surface. This leads to the formation of a stable bond on the surface.

Since the physical and chemical nature have decisive effects on the applicability of magnetic nanoparticles, comprehensive surface characterization techniques are utilized for a better understanding of the surface properties such as surface morphology, chemical composition and spatial distribution of the functional groups. Fundamental techniques [71-76] employed to investigate magnetic nanoparticles mainly include: Fourier transform infrared spectroscopy (FT-IR), scanning electron microscopy (SEM), transmission electron microscopy (TEM), X-ray photoelectron spectroscopy (XPS), atomic force microscopy (AFM), vibrating sample magnetometry (VSM), X-ray diffraction (XRD) analysis and thermal gravimetric analysis (TGA). 
Figure 1. Chemical structures of mostly used silane precursors for surface functionalization and silanization reaction mechnism on magnetic nanoparticle. (A) Organo-functional silane molecule structures contain two different basic reactive groups: an organic hydrolyzable group (OR) and an organo-functional group (F); (B) Schematic of the condensation reaction between silane molecules and an oxide surface. The $\mathrm{Si}-\mathrm{OR}$ bonds hydrolyze readily with water to form silanol $\mathrm{Si}-\mathrm{OH}$ groups, which can then condense with each other to form polymeric structures with hydroxyl groups on the material surface.

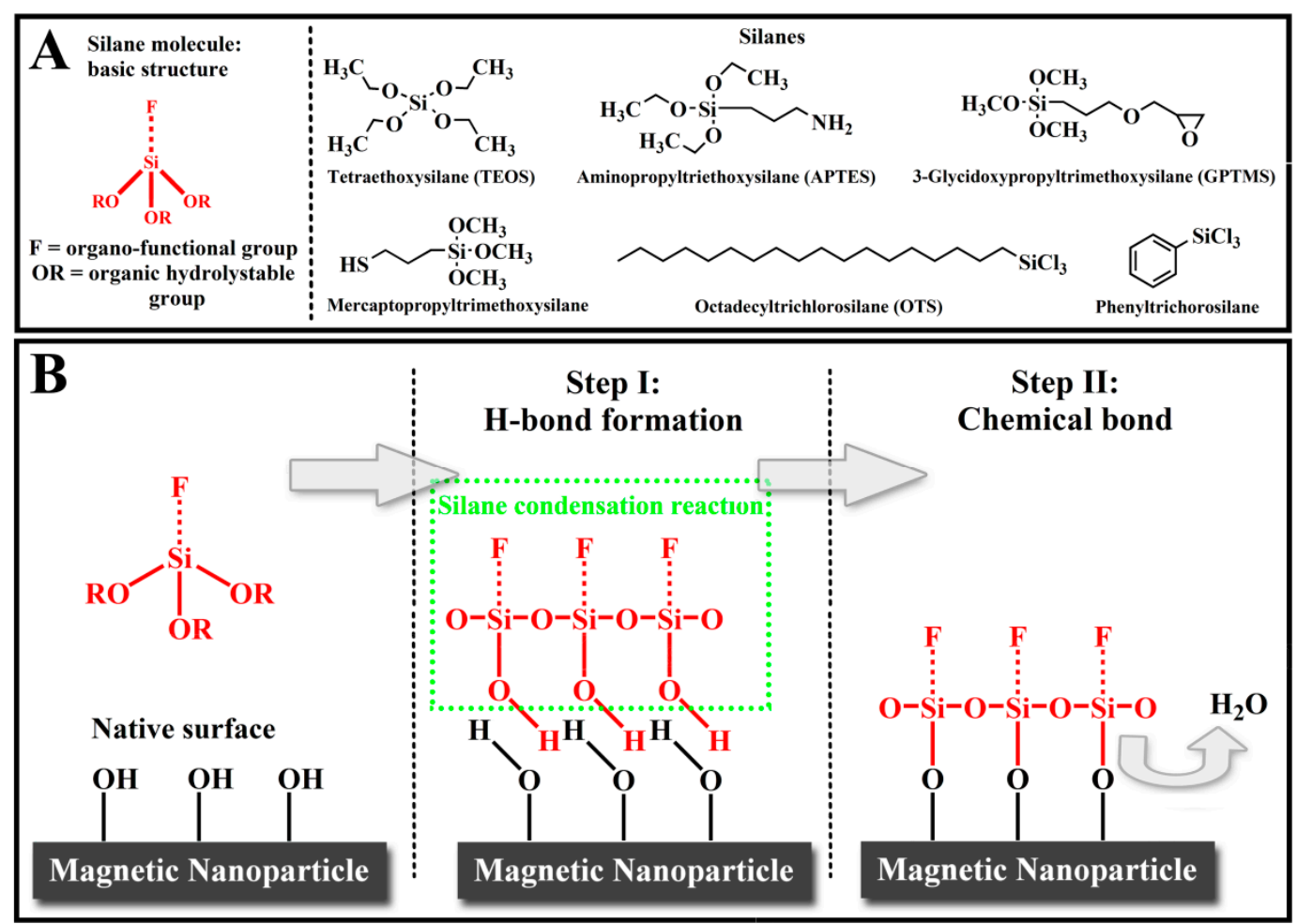

\section{Immobilization Methods}

Compared with the conventional immobilization methods, nanoparticle based immobilization can be characterized by two main features [77-81]: (i) the composition, size and morphology of particles can be conveniently tuned by changing the reaction conditions; (ii) uniform particles make it easy to perform the enzyme immobilization on a large scale without using surfactants and toxic reagents. The methods developed for protein immobilization onto iron magnetic nanoparticles mainly include physical immobilization, covalent conjugation and biologically-mediated specific interactions.

\subsection{Physical Immobilization}

Physical immobilization can be considered the simplest functionalization method employed in protein immobilization, as it may be easily carried out by just dipping the material into a solution containing the target biomolecules, and no additional coupling reagents, surface treatment and protein modification are required [82-84]. A good number of physically immobilized proteins based on iron magnetic nanoparticles have been developed. For example, glucose oxidase was immobilized onto $\mathrm{Fe}_{3} \mathrm{O}_{4}$ magnetic nanoparticles via physical method for water deoxygenation, and a $78 \%$ immobilization 
was obtained with specific activity of $640 \mathrm{U} / \mathrm{g}$ [85]. In another example, electrostatic interactions were employed to immobilize pectinase on negatively charged $\mathrm{AOT}-\mathrm{Fe}_{3} \mathrm{O}_{4}$ nanoparticles, and a maximum specific activity (1.98 U/mg enzyme) of immobilized pectinase and maximum enzyme loading of $610.5 \mathrm{mg}$ enzyme/g support was attained and the activity loss of immobilized protein was only $10 \%-20 \%$ after six cycles [86]. Although physical immobilization is simple and mild, this method generally involves comparatively weak interactions such as electrostatic interactions [87,88], hydrogen bonds [89], van der Waals forces [90-92], and hydrophobic interactions [93], and the binding stability of adsorbed species is highly affected by environmental conditions $(\mathrm{pH}$, temperature, ionic strength and biomolecule concentration). Therefore, proteins immobilized using this method tend to break away from the support, and thus lead to the loss of activity and contamination of the reaction media, which would affect the robustness and recyclability of the immobilized proteins, particularly for those constructed for analytical and detective use. Furthermore, protein adsorption directly onto surfaces often leads to the denaturation of proteins and losses in protein activity resulting from conformational changes caused by steric interaction.

\subsection{Covalent Conjugation}

Covalent immobilization is particularly attractive, as it could be carefully regulated with specific functional groups to bind to proteins. Several immobilization protocols using covalent binding have already been developed and employed in protein immobilization [94-97].

Coupling agents such as glutaraldehyde (GA) [98-102] and 1-ethyl-3-(3-dimethylaminopropyl) carbodiimide hydrochloride (EDC) [103-106] are often utilized to covalently cross-link the modified magnetic nanoparticles and proteins because their functional groups (e.g., aldehyde group) can interact with both functional groups of the modified magnetic nanoparticle and proteins. For example, glucose oxidase (GOD) was immobilized on $\mathrm{CoFe}_{2} \mathrm{O}_{4} / \mathrm{SiO}_{2}$ NPs via cross-linking with glutaraldehyde. After immobilization, the GOD exhibited improved thermal, storage and operation stability. The immobilized GOD still maintained $80 \%$ of its initial activity. After storage at $4{ }^{\circ} \mathrm{C}$ for 28 days, the immobilized and free enzyme retained $87 \%$ and $40 \%$ of initial activity, respectively [98]. In another example, the $\mathrm{Fe}_{3} \mathrm{O}_{4}$-chitosan nanoparticles are used for the covalent immobilization of lipase from Candida rugosa using $N$-(3-dimethylaminopropyl)- $N$ '-ethylcarbodiimide (EDC) and $N$-hydroxysuccinimide (NHS) as coupling agents. The optimum immobilization conditions were immobilization time $2.14 \mathrm{~h}, \mathrm{pH} 6.37$, and enzyme/support ratio $0.73(\mathrm{w} / \mathrm{w})$; the highest activity obtained was $20 \mathrm{U} / \mathrm{g} \mathrm{Fe}_{3} \mathrm{O}_{4}$-chitosan. The immobilized lipase retains over $83 \%$ of its initial activity after twenty repeated cycles [103]. However, in many cases, the presence of coupling agents could cause a conformational change of proteins, resulting in a decrease of enzyme activity. For example, the immobilized enzymes retained $15 \%-23 \%$ of the native glucose oxidase. Recycling stability studies showed approximately $20 \%$ of activity loss for the glucose oxidase-magnetic nanoparticle bioconjugate [107].

Several other enzymes have been successfully immobilized onto iron magnetic nanoparticles using this covalent method, e.g., lipase [108], Candida rugosa lipase [109], horseradish peroxidase [110-114], pectinase [115,116], trypsin [117-120], $\alpha$-chymotrypsin [121-127], cyclic adenosine monophosphatedependent protein kinase [128], glucose oxidase [129-135], hexaarginine-tagged esterase [136], 
porcine pancreas lipase papain [137], Saccharomyces cerevisiae alcohol dehydrogenase [138], chitosanase [139,140], triacylglycerol lipase [141], laccase (a copper oxidoreductase from a fungal source) [142-144], epoxide hydrolase [145,146], etc.

The main problem in the practical use of covalent immobilization is non-specificity, and purified proteins are generally involved in covalent immobilization. However, purification of proteins in large scale is really time-consuming and resource intensive, and the impurities rather than the target protein present in the mixture might also have strong tendency to bind to the support which would great affect its activity. Another aspect associated with covalent immobilization is once the activity of immobilized protein/enzyme decays, the support must be discarded together.

\subsection{Biologically Mediated Specific Interaction}

Many of the applications demonstrated thus far have relied on protein attachment methods that result in non-site-specific immobilization, either through adsorption or covalent attachment. However, such non-specificity greatly limits their application. Site-specific immobilization methods based on biological reactions have offered a novel route to solve the problem of selectivity, which could be achieved by the formation of bonds between the active groups on the supports and specific residues on the protein. By proper modification of the supports and protein engineering, such attachments could be strategically realized under mild conditions, which have greatly reduced the risk of protein degradation or denaturation.

The (strept)avidin-biotin technology probably ranks among the most extensively researched and frequently used protein-mediated immobilization technique that relies on biologically mediated immobilization methods [147] (Scheme 1). The biotin and (strept)avidin couple not only has a high binding affinity $\left(K_{\mathrm{d}} \approx 10^{-15} \mathrm{M}\right)$, but also exhibits high specificity, hence it finds potential application in protein immobilization. The four biotin binding sites positioned in pairs on a stretavidin's opposite domains can serve as a bridge between the immobilized biotinylated moiety and the target nanoparticles. The proteins functionalized with (strept)avidin are unusually stable to extremes such as heat, denaturants, $\mathrm{pH}$, and proteolysis, indicating the binding is essentially irreversible. For instance, Nidumolu's group reported the synthesis of streptavidin-functionalized magnetic nanoparticles and investigation of the binding to biotinylated SAMs on gold and glass for biological recognition applications [148]. The whole process includes three steps. Firstly, magnetic nanoparticles was prepared using traditional chemical coprecipitation method, which were then modified with the protein FITC-labeled streptavidin using carbodiimide activation. Secondly, gold and glass surfaces were functionalized with biotin SAMs by applying biotin-HPDP onto gold coated glass slides. Thirdly, the functionalized nanoparticles specifically bind to the biotinylated gold surfaces.

Even though the selectivity has contributed greatly to the popularity of this method as a means of protein immobilization, the protein of interest must first be labeled with biotin if site-selective attachment is desired. 
Scheme 1. Schematic illustration of protein immobilization onto iron magnetic nanoparticles using (strept)avidin-biotin technology.

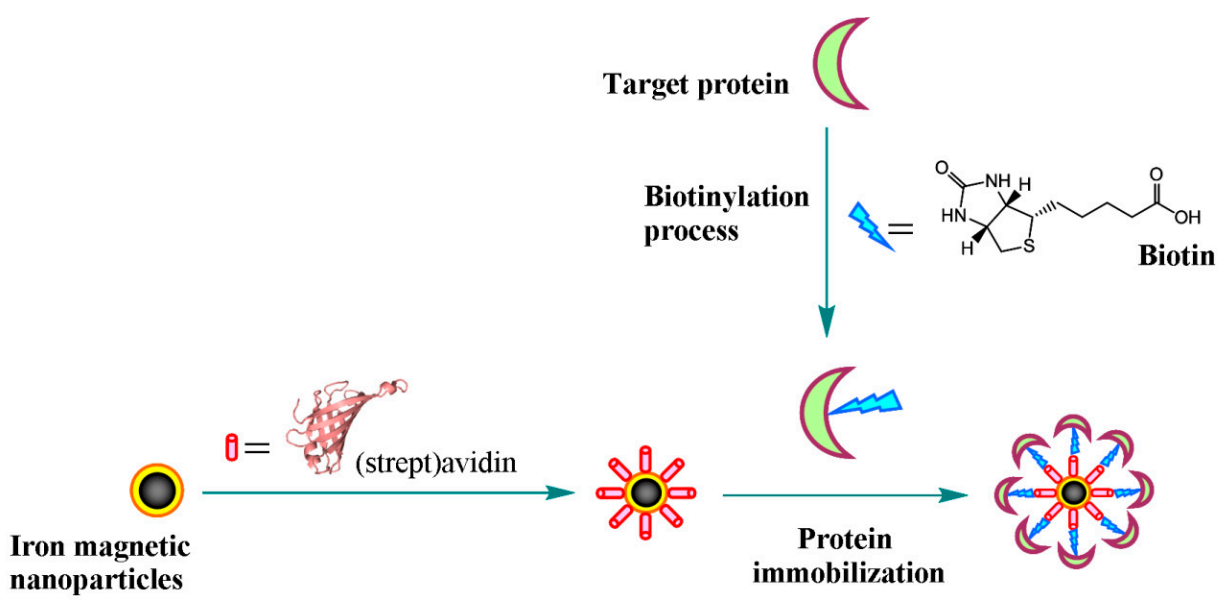

\section{Aplications of Magnetic Nanoparticles Immobilized Proteins}

Magnetic nanoparticles appear to be very promising for their applications in bioseparation, medical science, and environmental analysis. In this section, these applications will be discussed briefly.

\subsection{Bioseparation}

Affinity chromatography is one of the most efficient strategies for the efficient purification of recombinant protein due to the affinity interactions between metal ions (e.g., $\mathrm{Ni}^{2+}$ ) and polyhistidine affinity tag (His tag). Several functionalized MNPs have been developed for the specific separation of different proteins (Table 2).

Table 2. Examples of proteins separated by modified magnetic techniques [149].

\begin{tabular}{|c|c|c|c|c|}
\hline Protein & Magnetic carrier & Ligand & Elution method & $\begin{array}{c}\text { Reference } \\
\text { number }\end{array}$ \\
\hline \multirow{4}{*}{ Lysozyme } & $\mathrm{Fe}_{3} \mathrm{O}_{4} @ \mathrm{PEG} @ \mathrm{CM}-\mathrm{CTS}$ & $-\mathrm{COOH}$ & PBS containing $\mathrm{NaCl}$ & {$[150]$} \\
\hline & 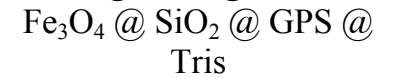 & Tris & $\mathrm{n} / \mathrm{a}$ & {$[151]$} \\
\hline & $\mathrm{Fe}_{3} \mathrm{O}_{4} @ \mathrm{PAA}$ & $-\mathrm{COOH}$ & Phosphate buffer containing NaSCN & {$[152]$} \\
\hline & Magnetic PHEMA beads @ & $\begin{array}{c}\text { Cibacron Blue } \\
\text { F3GA }\end{array}$ & Tris/ $\mathrm{HCl}$ buffer containing $\mathrm{NaCl}$ & {$[153]$} \\
\hline SOD & $\mathrm{Fe}_{3} \mathrm{O}_{4} @ \mathrm{IDA} @ \mathrm{Cu}^{2+}$ & IDA@ $\mathrm{Cu}^{2+}$ & $\begin{array}{c}\text { Potassium phosphate in the presence } \\
\text { of } \mathrm{NH}_{4} \mathrm{Cl}\end{array}$ & {$[154]$} \\
\hline Lipase & $\mathrm{Fe}_{3} \mathrm{O}_{4} @ \mathrm{PAA}$ & $-\mathrm{COOH}$ & Phosphate buffer ( $\mathrm{pH} 9)$ & {$[155]$} \\
\hline His-tag proteins & $\mathrm{Fe}_{3} \mathrm{O}_{4} @$ PMIDA-Ni ${ }^{2+}$ & PMIDA-Ni ${ }^{2+}$ & $\begin{array}{c}\text { Sodium phosphate, } \mathrm{NaCl} \text { and } \\
\text { imidazole }\end{array}$ & {$[156]$} \\
\hline Lactoferrin & $\begin{array}{c}\mathrm{Fe}_{3} \mathrm{O}_{4} @ \text { heparin } \\
\text { PGMA-EA @ }\end{array}$ & Heparin & $\mathrm{NaCl}$ & {$[157]$} \\
\hline $\mathrm{BHb}$ & 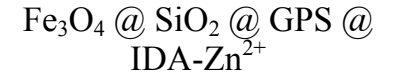 & $\mathrm{DA}-\mathrm{Zn}^{2+}$ & $\mathrm{n} / \mathrm{a}$ & {$[158]$} \\
\hline Antibody & $\begin{array}{c}\mathrm{Fe}_{3} \mathrm{O}_{4} @ \text { cellulose } @ \\
\text { protein A }\end{array}$ & Protein A & $\mathrm{n} / \mathrm{a}$ & [159] \\
\hline
\end{tabular}

$\mathrm{n} / \mathrm{a}$ Not available or not possible to determine from the information published. CM-CTS = carboxymethyl chitosan, GPS = 3-glycidoxypropyltrimethoxysilane, PEG = polyethylene glycol, Tris $=$ tris(hydroxymethyl)-amino-methane, PAA $=$ polyacrylic acid, $\mathrm{SOD}=$ superoxide dismutase, IDA $=$ iminodiacetic acid, PMIDA $=$ N-phosphonomethyl iminodiacetic acid, $\mathrm{EA}=$ ethanediamine, $\mathrm{PGMA}=$ polyglycidyl methacrylate, $\mathrm{BHb}=$ bovine haemoglobin. 
Once captured, the target proteins, in most cases, could be rapidly and completely eluted by using proper elution methods, generally, buffer solution with different $\mathrm{pH}$ or ion strength. The change of $\mathrm{pH}$ can change the surface electric charges of the protein and the support, and thus decrease the interaction between the protein and the ligand-immobilized magnetic nanoparticles. The increase of ion strength, usually realized by the addition of salts such as $\mathrm{Na}^{+}$, could reduce electrostatic reaction between the protein and the ligand-immobilized magnetic nanoparticles. Therefore, these two parameters are taken into account to select proper buffer for protein elution from the ligand-immobilized magnetic nanoparticles. However, the use of excessively high $(>10)$ or low $(<4) \mathrm{pH}$ for protein elution might significantly impact the bioactivity of proteins.

Imidazole, as an efficient and gentle regent, is very suitable for the elution of target proteins for metal ion chelated magnetic nanoparticles. Ma, Liu, Guan, and Liu [158,160] used imidazole solution as eluent for the elution of the adsorbed bovine serum albumin (BSA) from $\mathrm{Cu}^{2+}$ chelated magnetic nanoparticles and for the elution of $\mathrm{BHb}$ and $\mathrm{BSA}$ from $\mathrm{Zn}^{2+}$ chelated magnetic nanoparticles. Sahu et al. [156] used imidazole solution to elute His-tagged recombinant proteins for $\mathrm{Ni}^{2+}$ chelated magnetic nanoparticles. These metal ion chelated magnetic nanoparticles were usually regenerated by using EDTA to strip the adsorbed protein and metal ion and then reloading with metal ion for repeated use.

In comparison, several adsorbed proteins are difficult to elute from ligand-immobilized magnetic nanoparticles, which may be ascribed to the complex interactions between the ligands and target proteins or other factors. Zheng et al. prepared magnetic core-shell $\mathrm{Fe}_{3} \mathrm{O}_{4} @ \mathrm{SiO}_{2} @$ poly(styrene-alt-maleic anhydride) spheres for the separation of His-tagged proteins from cell lysates [161]. The enrichment capacity of this magnetic polymer was four times greater than that by $\mathrm{Fe}_{3} \mathrm{O}_{4} @ \mathrm{SiO}_{2} / \mathrm{Ni}-\mathrm{NTA}$. Also, Bruening et al. synthesized polymer-brush-modified MNPs functionalized with nitrilotriacetate- $\mathrm{Ni}^{2+}$ by ATRP to capture histagged proteins selectively from cell extracts [162]. The polymer brushes can dramatically increase the adsorption capacity for his-tagged ubiquitin and afford high protein recoveries. A novel three-component microsphere $\left(\mathrm{Fe}_{3} \mathrm{O}_{4} @ \mathrm{SiO}_{2} @ \mathrm{NiAl}-\mathrm{LDH}\right)$, which possesses large surface area and uniform mesochannels, was prepared by Wei et al. via an in situ growth method [163]. The $\mathrm{Fe}_{3} \mathrm{O}_{4} @ \mathrm{SiO}_{2} @ \mathrm{NiAl}-\mathrm{LDH}$ microspheres prepared showed a binding capacity of $239 \mu \mathrm{g} / \mathrm{mg}$ beads for the adsorption of His-tagged green fluorescent protein.

\subsection{Medical Science}

\subsubsection{Targeted Drug Delivery}

Drug delivery systems based on magnetic nanoparticle have major advantages over the conventional, non-targeted methods of drug delivery. In conventional drug delivery systems, the poor specificity for the target site and reduced drug diffusion through biological barriers often lead to a suboptimal pharmacological activity and high incidence of adverse effects. In contrast, magnetic nanoparticles are promising stimuli-sensitive drug carriers due to the better retention ability than those of small molecules. An applied extracorporeal magnetic field can concentrate these nanoparticles at the desired site to receive enough drug efficiency and an improved therapeutic activity, ensuring sustained but complete release of the immobilized drugs. In particular, nanoparticles in the range of 20-400 nm 
in diameter show tumor-selective integration known as the enhanced permeability and retention (EPR) effect.

Drugs whose therapeutic doses are low, but having strong electrostatic affinity toward MNPs, can be loaded directly by adsorption onto the nanoparticle surface. However, the drug loading just by surface adsorption is generally insufficient to reach the therapeutic drug concentration necessary at the target site. Thus, a core-shell structure including a magnetic core and a biodegradable organic or inorganic shell is usually employed in magnetic drug-delivery systems [164] to achieve sufficient drug payload. Once the drug carrier is concentrated at the target, the drug can be released either via enzymatic activity or changes in physiological conditions such as $\mathrm{pH}$, osmolality, or temperature, and may be internalized by the endothelial cells of the target tissue or be taken up by the tumour cells. For example, Jana et al. reported a targeted delivery of serratiopeptidase enzyme immobilized on magnetic nanoparticles of $\mathrm{Fe}_{3} \mathrm{O}_{4}$. This magnetic drug-delivery system increased the delivery of drug through the membrane in in vitro study and enhanced the anti-inflammatory effect on in rats in in vivo study [165].

\subsubsection{Bisensor}

Iron magnetic nanoparticles coated with other materials, such as a fluorescent ones, a metal, silica, or a polymer, are used as bioanalytical sensors. For example, $\mathrm{Fe} / \mathrm{Fe}_{2} \mathrm{O}_{3}$ core/shell nanoparticles attached with bioactive proteins such as cytochrome P450, myoglobin ( $\mathrm{Mb})$, and hemoglobin ( $\mathrm{Hb}$ ) are selectively used for the detection of damaged DNA [166,167]. Magnetic nanoparticles have been also applying in glucose biosensors which use immobilized oxidase for the conversion of the target analytes into electrochemically detectable products for the determination of glucose in foodstuff samples [149]. An iron oxide nanoparticles-chitosan composite based glucose biosensor was developed by Kaushik et al. [168]. This biosensor response time of $5 \mathrm{~s}$, linearity as $0.1-4 \mathrm{mg} / \mathrm{mL}$ of glucose, sensitivity as $\left.9.3 \times 10^{-2} \mathrm{~mA} /(\mathrm{mg} \mathrm{mL} \mathrm{cm})^{2}\right)$ and shelf life of about 8 weeks under refrigerated conditions. The use of iron oxide nanoparticles-chitosan composite enhanced the enzymatic activity and stability of glucose oxidase, which results in high sensitivity and long shelf life.

\subsubsection{Bioimaging}

Magnetic resonance imaging (MRI) is a commonly used non-invasive medical imaging technique in clinical medicine to visualize the structure and function of tissues $[169,170]$, which is based on the behavior, alignment and interaction of protons in the presence of an applied magnetic field. Due to prorpeties such as biocompatibility, high saturation magnetization, superparamagetism, and low toxicity, proteins immobilized on iron magnetic nanoparticles have been successfully applied in MRI imaging [171]. Human holo-transferrin conjugated to iron oxide nanoparticles showed that increases in receptor levels at the cell surface can cause considerable changes in MRI signals. These superparamagnetic iron oxide nanoparticles are relatively non-toxic when administered intravenously, and similar preparations are in clinical use. 


\subsection{Food Analysis}

Food safety has attracted increasing attention by consumers, governments, and manufacturers. Magnetic nanoparticles are usually integrated with detection techniques for food analysis by two ways: electrode modifier and sample pre-concentrator. For example, a protein A coated magnetic microparticles-based enzyme-linked immunosorbent assay method was developed for the detection of Ara h3/4 peanut allergen in foods, which had a detection limit as low as $0.2 \mathrm{mg} / \mathrm{kg}$ and achieved excellent precision and repeatability [172].

\section{Concluding Remarks and Prospects}

Nanoparticles have emerged as versatile tools for generating excellent supports for enzyme stabilization due to their small size and large surface area. By proper surface modification, various iron magnetic nanoparticles have been synthesized and successfully utilized for protein/enzyme immobilization, which have already displayed promising effects in practical applications. We have summarized in this review the applications of iron magnetic nanoparticles in enzyme immobilization, protein separation/purification, medical science and food analysis. The immobilized proteins/enzymes generally show better stability towards $\mathrm{pH}$ and heat than the free ones and can be recovered and reused multiple times. However, the activity of some enzymes decreases to some extent after immobilization, which indicates that more efforts are still required to explore the immobilization techniques.

\section{Acknowledgments}

The authors thank International Science \& Technology Cooperation Program of China (2011DFB30250 and 2014DFG30890), Qingdao Scientific and Technological Achievements Transformation Program (14-2-4-91-jch), National High Technology Research and Development Program of China (2011AA090703), National Natural Science Foundation of China (NSFC) (31200642), Special Scientific Research Funds for Central Non-profit Institutes, Chinese Academy of Fishery Sciences (2013A1002), and Qingdao Municipal Science and Technology Plan Project (12-1-4-12-(2)-jch) for financial support.

\section{Author Contributions}

J.K.X.: conception, design, and manuscript preparation; J.J.S.: manuscript preparation; Y.J.W.: review of the manuscript; J.S.: review of the manuscript; F.W.: review of the manuscript; M.S.: conception and review of the manuscript.

\section{Conflicts of Interest}

The authors declare no conflict of interest.

\section{References}

1. Kim, J.; Gratea, J.W.; Wang, P. Nanostructures for enzyme stabilization. Chem. Eng. Sci. 2006, 61, 1017-1026. 
2. Tischer, W.; Wedekind, F. Immobilized Enzymes: Methods and Applications. Top. Curr. Chem. 1999, 200, 95-126.

3. Zhang, S.; Gao, S.; Gao, G. Immobilization of $\beta$-galactosidase onto magnetic beads. Appl. Biochem. Biotech. 2010, 160, 1386-1393.

4. Martin, C.R.; Kohli, P. The emerging field of nanotube biotechnology. Nat. Rev. Drug. Discov. 2003, 2, 29-37.

5. Yim, T.J.; Kim, D.Y.; Karajanagi, S.S.; Lu, T.M.; Kane, R.; Dordick, J.S. Silicon nanocolumns as novel nanostructured supports for enzyme immobilization. J. Nanosci. Nanotechnol. 2003, 3, 479-482.

6. Romdhane, I.B.B.; Romdhane, Z.B.; Gargouri, A.; Belghith, H. Esterification activity and stability of Talaromyces thermophilus lipase immobilized onto chitosan. J. Mol. Catal. B-Enzym. 2011, 68, 230-239.

7. Stepankova, V.; Bidmanova, S.; Koudelakova, T.; Prokop, Z.; Chaloupkova, R.; Damborsky, J. Strategies for stabilization of enzymes in organic solvents. ACS Catal. 2013, 3, 2823-2836.

8. Garcia-Galan, C.; Berenguer-Murcia, A.; Fernandez-Lafuente, R.; Rodrigues, R.C. Potential of different enzyme immobilization strategies to improve enzyme performance. Adv. Synth. Catal. 2011, 353, 2885-2904.

9. Brady, D.; Jordaan, J. Advances in enzyme immobilization. Biotechnol. Lett. 2009, 31, 1639-1650.

10. Iyer, P.V.; Ananthanarayan, L. Enzyme stability and stabilization-Aqueous and non-aqueous environment. Process Biochem. 2008, 43, 1019-1032.

11. Sheldon, R.A.; Schoevaart, R.; van Langen, L.M. Cross-Linked Enzyme Aggregates. Methods Biotechnol. 2006, 22, 31-45.

12. Mateo, C.; Palomo, J.M.; van Langen, L.M.; van Rantwijk, F.; Sheldon, R.A. A new, mild cross-linking methodology to prepare cross-linked enzyme aggregates. Biotechnol. Bioeng. 2004, $86,273-276$.

13. Fernandez-Lafuente, R. Stabilization of multimeric enzymes: Strategies to prevent subunit dissociation. Enzyme Microb. Technol. 2009, 45, 405-418.

14. Bezbradica, D.; Mijin, D.; Mihailović, M.; Knežević-Jugović, Z. Microwave-assisted immobilization of lipase from Candida rugosa on Eupergit ${ }^{\circledR}$ supports. J. Chem. Technol. Biot. 2009, 84, 1642-1648.

15. Schlossbauer, A.; Schaffert, D.; Kecht, J.; Wagner, E.; Bein, T. Click Chemistry for High-Density Biofunctionalization of Mesoporous Silica. J. Am. Chem. Soc. 2008, 130, 12558-12559.

16. Wang, Y.; Caruso F. Mesoporous Silica Spheres as Supports for Enzyme Immobilization and Encapsulation. Chem. Mater. 2005, 17, 953-961.

17. Yáñez-Sedeño, P.; Pingarrón, J.M. Gold nanoparticle-based electrochemical biosensors. Electrochim. Acta 2005, 382, 4, 884-886.

18. Tang, D.; Su, B.; Tang, J.; Ren, J.; Chen, G. Nanoparticle-Based Sandwich Electrochemical Immunoassay for Carbohydrate Antigen 125 with Signal Enhancement Using Enzyme-Coated Nanometer-Sized Enzyme-Doped Silica Beads. Anal. Chem. 2010, 82, 1527-1534.

19. Kim, J.; Kim, B.C.; Lopez-Ferrer, D.; Petritis, K.; Smith, R.D. Nanobiocatalysis for protein digestion in proteomic analysis. Proteomics 2010, 10, 687-699. 
20. Laurent, S.; Forge, D.; Port, M.; Roch, A.; Robic, C.; Elst, L.V.; Muller, R.N. Magnetic iron oxide nanoparticles: Synthesis, stabilization, vectorization, physicochemical characterizations, and biological applications. Chem. Rev. 2008, 108, 2064-2110.

21. Sun, C.; Lee, J.S.H.; Zhang, M. Magnetic nanoparticles in MR imaging and drug delivery. Adv. Drug Delivery Rev. 2008, 60, 1252-1265.

22. Xu, P.; Zeng, G.M.; Huang, D.L.; Feng, C.L.; Hu, S.; Zhao, M.H.; Lai, C.; Wei, Z.; Huang, C.; Xie, G.X.; et al. Use of iron oxide nanomaterials in wastewater treatment: A review. Sci. Total Environ. 2012, 424, 1-10.

23. Xu, P.; Zeng, G.M.; Huang, D.L.; Lai, C.; Zhao, M.H.; Wei, Z.; Li, N.J.; Huang, C.; Xie, G.X. Adsorption of $\mathrm{Pb}(\mathrm{II})$ by iron oxide nanoparticles immobilized Phanerochaete chrysosporium: Equilibrium, kinetic, thermodynamic and mechanisms analysis. Chem. Eng. J. 2012, 203, 423-431.

24. Tang, W.W.; Zeng, G.M.; Gong, J.L.; Liang, J.; Xu, P.; Zhang, C.; Huang, B.B. Removal of heavy metals from aqueous solutions using nanomaterials affected by humic/fulvic acid: A review. Sci. Total Environ. 2014, 468-469, 1014-1027.

25. Colombié, S.; Gaunand, A.; Lindet, B. Lysozyme inactivation under mechanical stirring: Effect of physical and molecular interfaces. Enzyme Microb. Technol. 2001, 28, 820-826.

26. Wu, H.; Fan, Y.; Sheng, J.; Sui, S.F. Induction of changes in the secondary structure of globular proteins by a hydrophobic surface. Eur. Biophys. J. Biophys.1993, 22, 201-205.

27. Durán, J.D.G.; Arias, J.L.; Gallardo, V.; Delgado, A.V. Magnetic colloids as drug vehicles. J. Pharm. Sci. 2008, 97, 2948-2983.

28. Jain, T.K.; Reddy, M.K.; Morales, M.A.; Leslie-Pelecky, D.L.; Labhasetwar, V. Biodistribution, Clearance, and Biocompatibility of Iron Oxide Magnetic Nanoparticles in Rats. Mol. Pharmaceutics 2008, 5, 316-327.

29. Liu, Y.; Jia, S.; Wu, Q.; Ran, J.; Zhang, W.; Wu, S. Studies of $\mathrm{Fe}_{3} \mathrm{O}_{4}$-chitosan nanoparticles prepared by co-precipitation under the magnetic field for lipase immobilization. Catal. Comm. 2011, 12, 717-720.

30. Gao, J.; Gu, H.; Xu, B. Multifunctional Magnetic Nanoparticles: Design, Synthesis, and Biomedical Applications. Acc. Chem. Res. 2009, 42, 1097-1107.

31. Shubayev V.I.; Pisanic, T.R., 2nd; Jin, S. Magnetic nanoparticles for theragnostics. Adv. Drug Deliv. Rev. 2009, 61, 467-477.

32. Zhao, G.X.; Wen, T.; Yang, X.; Yang, S.B.; Liao, J.L.; Hu, J.; Shao, D.D.; Wang, X.K. Preconcentration of U(VI) ions on few-layered graphene oxide nanosheets from aqueous solutions, Dalton Trans. 2012, 41, 6182-6188.

33. Zong, P.F.; Wang, S.F.; Zhao, Y.L.; Wang, H.; Pan, H.; He, C.H. Synthesis and application of magnetic graphene/iron oxides composite for the removal of U(VI) from aqueous solutions. Chem. Eng. J. 2013, 220, 45-52.

34. Reddy, L.H.; Arias, J.L.; Nicolas, J.; Couvreur, P. Magnetic Nanoparticles: Design and Characterization, Toxicity and Biocompatibility, Pharmaceutical and Biomedical Applications Chem. Rev. 2012, 112, 5818-5878.

35. King, J.G.; Williams, W.; Wilkinson, C.D.W.; McVite, S.; Chapman, J.N. Magnetic properties of magnetite arrays produced by the method of electron beam lithography. Geophys. Res. Lett. 1996, 23, 2847-2850. 
36. Rishton, A.; Lu, Y.; Altman, R.A.; Marley, A.C.; Bian Hahnes, C.; Viswanathan, R.; Xiao, G.; Gallagher, W.J.; Parkin, S.S.P. Magnetic tunnel junctions fabricated at tenth-micron dimensions by electron beam lithography. Microelectron. Eng. 1997, 35, 249-252.

37. Lee, C.S.; Lee, H.; Westervelt, R.M. Microelectromagnets for the Control of Magnetic Nanoparticles. Appl. Phys. Lett. 2001, 79, 3308-3310.

38. Mathur, S.; Barth, S.; Werner, U.; Hernandez-Ramirez, F.; Romano-Rodriguez, A. Chemical Vapor Growth of One-dimensional Magnetite Nanostructures. Adv. Mater. 2008, 20, 1550-1554.

39. Da Costa, G.M.; de Grave, E.; de Bakker, P.M.A.; Vandenberghe, R.E.J. Synthesis and Characterization of Some Iron Oxides by Sol-Gel Method. Solid State Chem. 1994, 113, 405-412.

40. Itoh, H.; Sugimoto, T.J. Systematic control of size, shape, structure, and magnetic properties of uniform magnetite and maghemite particles. J. Colloid Interface Sci. 2003, 265, 283-295.

41. Amemiya, Y.; Arakaki, A.; Staniland, S.S.; Tanaka, T.; Matsunaga, T. Controlled formation of magnetite crystal by partial oxidation of ferrous hydroxide in the presence of recombinant magnetotactic bacterial protein Mms6. Biomaterials 2007, 28, 5381-5389.

42. Vereda, F.; Rodríguez-González, B.; de Vicente, J.; Hidalgo-Álvarez, R.J. Evidence of direct crystal growth and presence of hollow microspheres in magnetite particles prepared by oxidation of $\mathrm{Fe}(\mathrm{OH})_{2}$. J. Colloid Interface Sci. 2008, 318, 520-524.

43. Massart, R. Preparation of aqueous magnetic liquids in alkaline and acidic media. IEEE Trans. Magn. 1981, 17, 1247-1248.

44. Estévez, M.; Vargas, S.; Castaño, V.M.; Rodríguez, J.R.; Lobland, H.E.H.; Brostow, W. Novel wear resistant and low toxicity dental obturation materials. Mater. Lett. 2007, 61, 3025-3029.

45. Khollam, Y.B.; Dhage, S.R.; Potdar, H.S.; Deshpande, S.B.; Bakare, P.P.; Kulkarni, S.D.; Date, S.K. Microwave hydrothermal preparation of submicron-sized spherical magnetite $\left(\mathrm{Fe}_{3} \mathrm{O}_{4}\right)$ powders. Mater. Lett. 2002, 56, 571-577.

46. Chen, F.; Gao, Q.; Hong, G.; Ni, J. Synthesis and characterization of magnetite dodecahedron nanostructure by hydrothermal method. J. Magn. Magn. Mater. 2008, 320, 1775-1780.

47. Salazar-Alvarez, G.; Muhammed, M.; Zagorodni, A.A. Novel flow injection synthesis of iron oxide nanoparticles with narrow size distribution. Chem. Eng. Sci. 2006, 61, 4625-4633.

48. Cabrera, L.; Gutierrez, S.; Menendes, N.; Morales, M.P.; Herrasti, P. Magnetite nanoparticles: Electrochemical synthesis and characterization. Electrochim. Acta 2008, 53, 3436-3441.

49. Marques, R.F.C.; Garcia, C.; Lecante, P.; Ribeiro, J.L.; Noé, L.; Silva, N.J.O.; Amaral, V.S.; Millan, A.; Verelst, M. Electro-precipitation of $\mathrm{Fe}_{3} \mathrm{O}_{4}$ nanoparticles in ethanol. J. Magn. Magn. Mater. 2008, 320, 2311-2315.

50. González-Carreño, T.; Morales, M.P.; Gracia, M.; Serna, C.J. Preparation of uniform $\gamma-\mathrm{Fe}_{2} \mathrm{O}_{3}$ particles with nanometer size by spray pyrolysis. Mater. Lett. 1993, 18, 151-155.

51. Strobel, R.; Pratsinis, S.E. Direct synthesis of maghemite, magnetite and wustite nanoparticles by flame spray pyrolysis. Adv. Powder Technol. 2009, 20, 190-194.

52. Enomoto, N.; Akagi, J.; Nakagawa, Z. Sonochemical powder processing of iron hydroxides. Ultrason. Sonochem. 1996, 3, 97-103.

53. Dang, F.; Enomoto, N.; Hojo, J.; Enpuku, K. Sonochemical synthesis of monodispersed magnetite nanoparticles by using an ethanol-water mixed solvent. Ultrason. Sonochem. 2009, 16, $649-654$. 
54. Eckert, C.A.; Knutson, B.L.; Debenedetti, P.G. Supercritical fluids as solvents for chemical and materials processing. Nature 1996, 383, 313-318.

55. Teng Lam, U.; Mammucari, R.; Suzuki, K.; Foster, N.R. Processing of Iron Oxide Nanoparticles by Supercritical Fluids. Ind. Eng. Chem. Res. 2008, 47, 599-614.

56. Breulmann, M.; Colfen, H.; Hentze, H.P.; Antonietti, M.; Walsh, D.; Mann, S. Elastic magnets: Template-controlled mineralization of iron oxide colloids in a sponge-like gel matrix. Adv. Mater. 1998, 10, 237-240.

57. Liu, J.F.; Lua, M.F.; Chaia, P.; Fua, L.; Wang, Z.L.; Cao, X.Q.; Meng, J. The magnetic and structural properties of hydrothermal-synthesized single-crystal $\mathrm{Sn}_{1-x} \mathrm{Fe}_{x} \mathrm{O}_{2}$ nanograins. J. Magn. Magn. Mater. 2007, 317, 1-7.

58. Narayanan, K.B.; Sakthivel, N. Biological synthesis of metal nanoparticles by microbes. Adv. Colloid Interface Sci. 2010, 156, 1-13.

59. Moon, J.W.; Roh, Y.; Lauf, R.J.; Vali, H.; Yeary, L.W.; Phelps, T.J. Microbial preparation of metal-substituted magnetite nanoparticles. J. Microbiol. Methods 2007, 70, 150-158.

60. Moon, J.W.; Rawn, C.J.; Rondinone, A.J.; Love, L.J.; Roh, Y.; Everett, S.M.; Lauf, R.J.; Phelps, T.J.J. Large-scale production of magnetic nanoparticles using bacterial fermentation. Ind. Microbiol. Biotechnol. 2010, 37, 1023-1031.

61. Wu, J.H.; Ko, S.P.; Liu, H.L.; Kim, S.; Ju, J.S.; Kim, Y.K. Sub 5 nm magnetite nanoparticles: Synthesis, microstructure, and magnetic properties. Mater. Lett. 2007, 61, 3124-3129.

62. Viota, J.L.; Durán, J.D.G.; González-Caballero, F.; Delgado, A.V. Magnetic properties of extremely bimodal magnetite suspensions. J. Magn. Magn. Mater. 2007, 314, 80-86.

63. Mahmoudi, M.; Sant, S.; Wang, B.; Laurent, S.; Sen, T. Superparamagnetic iron oxide nanoparticles (SPIONs): Development, surface modification and applications in chemotherapy. Adv. Drug Deliver. Rev. 2011, 63, 24-46.

64. Sahoo, Y.; Pizem, H.; Fried, T.; Golodnitsky, D.; Burstein, L.; Sukenik, C.N.; Markovich, G. Alkyl phosphonate/phosphate coating on magnetite nanoparticles: A comparison with fatty acids. Langmuir 2001, 17, 7907-7911.

65. Lee, H.; Lee, E.; Kim, D.K.; Jang, N.K.; Jeong, Y.Y.; Jon, S. Antibiofouling polymer-coated superparamagnetic iron oxide nanoparticles as potential magnetic resonance contrast agents for in vivo cancer imaging. J. Am. Chem. Soc. 2006, 128, 7383-7389.

66. Souza, K.C.; Ardisson, J.D.; Sousa, E.M.B. Study of mesoporous silica/magnetite systems in drug controlled release. J. Mater. Sci.-Mater. Med. 2009, 20, 507-512.

67. Sun, C.; Veiseh, O.; Gunn, J.; Fang, C.; Hansen, S.; Lee, D.; Sze, R.; Ellenbogen, R.G.; Olson, J.; Zhang, M. In vivo MRI detection of gliomas by chloroto xin-conjugated superparamagnetic nanoprobes. Small 2008, 4, 372-379.

68. Mahmoudi, M.; Simchi, A.; Imani, M.; Milani, A.S.; Stroeve, P. In Vivo MRI Detection of Gliomas by Chlorotoxin-Conjugated Superparamagnetic Nanoprobes. J. Phys. Chem. B 2008, $112,14470-14481$.

69. Liu, H.L.; Ko, S.P.; Wu, J.H.; Jung, M.H.; Min, J.H.; Lee, J.H.; An, B.H.; Kim, Y.K. One-pot polyol synthesis of monosize PVP-coated sub-5 nm $\mathrm{Fe}_{3} \mathrm{O}_{4}$ nanoparticles for biomedical applications. J. Magn. Magn. Mater. 2007, 310, 815-817. 
70. Treccani, L.; Klein, T.Y.; Meder, F.; Pardun, K.; Rezwan, K. Functionalized ceramics for biomedical, biotechnological and environmental application. Acta. Biomater. 2013, 9, 7115-7150.

71. Arias, J.L.; López-Viota, M.; Ruiz, M.A.; López-Viota, J.; Delgado, A.V. Development of carbonyl iron/ethylcellulose core/shell nanoparticles for biomedical applications. Int. J. Pharm. 2007, 339, 237-245.

72. Donegá, C.M.; Liljeroth, P.; Vanmaekelbergh, D. Physicochemical evaluation of the hot-injection method, a synthesis route for monodisperse nanocrystals. Small 2005, 12, 1152-1162.

73. Arias, J.L.; Reddy, L.H.; Couvreur, P. Magnetoresponsive squalenoyl gemcitabine composite nanoparticles for cancer active targeting. Langmuir 2008, 24, 7512-7519.

74. Di Marco, M.; Sadun, C.; Port, M.; Guilbert, I.; Couvreur, P.; Dubernet, C. Physicochemical characterization of ultrasmall superparamagnetic iron oxide particles (USPIO) for biomedical application as MRI contrast agents. Int. J. Nanomed. 2007, 2, 609-622.

75. Jung, C.W. Surface properties of superparamagnetic iron oxide MR contrast agents: Ferumoxides, ferumoxtran, ferumoxsil. Magn. Reson. Imaging 1995, 13, 675-691.

76. Jung, C.W.; Jacobs, P. Physical and chemical properties of superparamagnetic iron oxide MR contrast agents: Ferumoxides, ferumoxtran, ferumoxsil. Magn. Reson. Imaging 1995, 13, 661-674.

77. Yang, H.; Zhang, S.; Chen, X.; Zhuang, Z.; Xu, J.; Wang, X. Magnetite-containing spherical silica nanoparticles for biocatalysis and bioseparations. Anal. Chem. 2004, 76, 1316-1321.

78. Ansari, S.A.; Husain, Q. Potential applications of enzymes immobilized on/in nano materials: A review. Biotechnol. Adv. 2012, 30, 512-523.

79. Kim, M.I.; Ham, H.O.; S.D., Oh; Park, H.G.; Chang, H.N.; Choi, S.H. Immobilization of Mucor javanicus lipase on effectively functionalized silica nanoparticles. J. Mol. Catal. B-Enzym. 2006, 39, 62-68.

80. Verma, M.L.; Barrow, C.J.; Puri, M. Nanobiotechnology as a novel paradigm for enzyme immobilisation and stabilisation with potential applications in biodiesel production. Appl. Microbiol. Biot. 2013, 97, 23-39.

81. Hwang, E.T.; Gu, M.B. Enzyme stabilization by nano/microsized hybrid materials. Eng. Life Sci. 2013, 13, 49-61.

82. Ozturk, N.; Akgol, S.; Arısoy, M.; Denizli, A. Reversible adsorption of lipase on novel hydrophobic nanospheres. Sep. Purif. Technol. 2007, 58, 83-90.

83. Valdes-Solis, T.; Rebolledo, A.F.; Sevilla, M.; Valle-Vigon, P.; Bomati-Miguel, O.; Fuertes, A.B.; Tartaj, P. Preparation, Characterization, and Enzyme Immobilization Capacities of Superparamagnetic Silica/Iron Oxide Nanocomposites with Mesostructured Porosity. Chem. Mater. 2009, 21, 1806-1814.

84. Betancor, L.; Luckarift, H.R. Bioinspired enzyme encapsulation for biocatalysis. Trends Biotechnol. 2008, 26, 566-572.

85. Mahdizadeh, F.; Karimi, A.; Ranjbarian, L. Immobilization of Glucose Oxidase on Synthesized Superparamagnetic $\mathrm{Fe}_{3} \mathrm{O}_{4}$ Nanoparticles; Application for Water Deoxygenation. Int. J. Sci. Eng. Res. 2012, 3, 516-520.

86. Bahrami, A.; Hejazi, P. Electrostatic immobilization of pectinase on negatively charged AOT-Fe ${ }_{3} \mathrm{O}_{4}$ nanoparticles. J. Mol. Catal. B-Enzym. 2013, 93, 1-7. 
87. Guisan, J.M. Immobilization of Enzymes and Cells, 2nd ed.; Humana Press Inc.: Madrid, Spain, 2006.

88. Liang, Y.-Y.; Zhang, L.-M.; Li, W.; Chen, R.-F. Polysaccharide-modified iron oxide nanoparticles as an effective magnetic affinity adsorbent for bovine serum albumin. Colloid Polym. Sci. 2007, 285, 1193-1199.

89. Joshi, M.D.; Sidhu, G.; Pot, I.; Brayer, G.D.; Withers, S.G.; McIntosh, L.P. Hydrogen bonding and catalysis: A novel explanation for how a single amino acid substitution can change the $\mathrm{pH}$ optimum of a glycosidase. J. Mol. Biol. 2000, 299, 255-279.

90. Zhang, Y.; Li, J.; Han, D.; Zhang, H.; Liu, P.; Li, C. An efficient resolution of racemic secondary alcohols on magnetically separable biocatalyst. Biochem. Biophys. Res. Commun. 2008, 365, 609-613.

91. Vijayalakshmi, A.; Tarunashree, Y.; Baruwati, B.; Manorama, S.V.; Narayana, B.L.; Johnson, R.E.C.; Raoa, N.M. Enzyme field effect transistor (ENFET) for estimation of triglycerides using magnetic nanoparticles. Biosens. Bioelectron. 2008, 23, 1708-1714.

92. Chen, J.-P.; Lin, W.-S. Sol-gel powders and supported sol-gel polymers for immobilization of lipase in ester synthesis. Enzyme Microb. Technol. 2003, 32, 801-811.

93. Johnson, A.K.; Zawadzka, A.M.; Deobald, L.A.; Crawford, R.L.; Paszczynski, A.J. Novel method for immobilization of enzymes to magnetic nanoparticles. J. Nanopart. Res. 2008, 10, 1009-1025.

94. Mateo, C.; Palomo, J.M.; Fernandez-Lorente, G.; Guisan, J.M.; Fernandez-Lafuente, R. Improvement of enzyme activity, stability and selectivity via immobilization techniques. Enzyme Microb. Technol. 2007, 40, 1451-1463.

95. Cowan, D.A.; Fernandez-Lafuente, R. Enhancing the functional properties of thermophilic enzymes by chemical modification and immobilization. Enzyme Microb. Technol. 2011, 49, 326-346.

96. Hernandez, K.; Fernandez-Lafuente, R. Control of protein immobilization: Coupling immobilization and site-directed mutagenesis to improve biocatalyst or biosensor performance. Enzyme Microb. Technol. 2011, 48, 107-122.

97. Barbosa, O.; Torres, R.; Ortiz, C.; Berenguer-Murcia, A.; Rodrigues, R.C.; Fernandez-Lafuente, R. Heterofunctional supports in enzyme immobilization: From traditional immobilization protocols to opportunities in tuning enzyme properties. Biomacromolecules 2013, 14, 2433-2462.

98. Wang, H.; Huang, J.; Wang, C.; Li, D.; Ding, L.; Han, Y. Immobilization of glucose oxidase using $\mathrm{CoFe}_{2} \mathrm{O}_{4} / \mathrm{SiO}_{2}$ nanoparticles as carrier. Appl. Surf. Sci. 2011, 257, 5739-5745.

99. Pan, C.; Hu, B.; Li, W.; Sun, Y.; Ye, H.; Zeng, X. Novel and efficient method for immobilization and stabilization of $\beta$-d-galactosidase by covalent attachment onto magnetic $\mathrm{Fe}_{3} \mathrm{O}_{4}$-chitosan nanoparticles. J. Mol. Catal. B-Enzym. 2009, 61, 208-215.

100. Yiğitoğlu, M.; Temoçin, Z. Immobilization of Candida rugosa lipase on glutaraldehyde-activated polyester fiber and its application for hydrolysis of some vegetable oils. J. Mol. Catal. B-Enzym. 2010, 66, 130-135.

101. Kanimozhi, S.; Perinbam K. Biodesel production from Pseudomonas fluorescens Lp1 lipase immobilized on aminosilane modified super paramagnetic $\mathrm{Fe}_{3} \mathrm{O}_{4}$ nanoparticles. J. Phys. Conf. Ser. 2013, 431, doi:10.1088/1742-6596/431/1/012010. 
102. Xia, T.; Guan, Y.; Yang, M.; Xiong, W.; Wang, N.; Zhao, S.; Guo, C. Synthesis of polyethylenimine modified $\mathrm{Fe}_{3} \mathrm{O}_{4}$ nanoparticles with immobilized $\mathrm{Cu}^{2+}$ for highly efficient proteins adsorption. Colloid Surf. A-Physicochem. Eng. Asp. 2014, 443, 552-559.

103. Kuo, C.-H.; Liu, Y.-C.; Chang, C.-M.J.; Chen, J.-H.; Chang, C.; Shieh, C.-J. Optimum conditions for lipase immobilization on chitosan-coated $\mathrm{Fe}_{3} \mathrm{O}_{4}$ nanoparticles. Carbohydr. Res. 2012, 87, 2538-2545.

104. Sui, Y.; Cui, Y.; Nie, Y.; Xia, G.-M.; Sun, G.-X.; Han, J.-T. Surface modification of magnetite nanoparticles using gluconic acid and their application in immobilized lipase. Colloid. Surface B 2012, 93, 24-28.

105. Lai, B.-H.; Yeh, C.-C.; Chen, D.-H. Surface modification of iron oxide nanoparticles with polyarginine as a highly positively charged magnetic nano-adsorbent for fast and effective recovery of acid proteins. Process Biochem. 2012, 47, 799-805.

106. Kouassi, G.K.; Irudayaraj, J.; McCarty, G. Activity of glucose oxidase functionalized onto magnetic nanoparticles. BioMagn. Res. Technol. 2005, 3, 1-10.

107. Park, H.J.; McConnell, J.T.; Boddohi, S.; Kipper, M.J.; Johnson, P.A. Synthesis and characterization of enzyme-magnetic nanoparticle complexes: Effect of size on activity and recovery. Colloid. Surface B 2011, 83, 198-203.

108. Xu, J.; Ju, C.; Sheng, J.; Wang, F.; Zhang, Q.; Sun, G.; Sun, M. Synthesis and Characterization of Magnetic Nanoparticles and Its Application in Lipase Immobilization. Bull. Korean Chem. Soc. 2013, 34, 2408-2012.

109. Yilmaz, E.; Sezgin, M.; Yilmaz, M. Immobilization of Candida rugosa lipase on magnetic sol-gel composite supports for enzymatic resolution of (R,S)-Naproxen methyl ester. J. Mol. Catal. B-Enzym. 2011, 69, 35-41.

110. Dong, J.; Kun, Z.; Tang, T.; Ai, S. Enzyme-catalyzed removal of bisphenol A by using horseradish peroxidase immobilized on magnetic silk fibroin microspheres. Res. J. Chem. Environ. 2011, 15, 13-18.

111. Chalkias, N.G.; Kahawong, P.; Giannelis, E.P. Activity increase of horseradish peroxidase in the presence of magnetic particles. J. Am. Chem. Soc. 2008, 130, 2910-2911.

112. Qu, S.; Huang, F.; Chen, G.; Yu, S.; Kong, J. Magnetic assembled electrochemical platform using Fe2O3 filled carbon nanotubes and enzyme. Electrochem. Commun. 2007, 9, 2812-2816.

113. Zhuo, Y.; Yuan, P.-X.; Yuan, R.; Chai, Y.-Q.; Hong, C.-L. Bienzyme functionalized three-layer composite magnetic nanoparticles for electrochemical immunosensors. Biomaterials 2009, 30, 2284-2290.

114. Eguilaz, M.; Villalonga, R.; Yáñez-Sedeño, P.; Pingarron, J.M. Designing Electrochemical Interfaces with Functionalized Magnetic Nanoparticles and Wrapped Carbon Nanotubes as Platforms for the Construction of High-Performance Bienzyme Biosensors. Anal. Chem. 2011, 83, 7807-7814.

115. Illanes, A. Enzyme Biocatalysis: Principles and Applications; Springer Science: Dordrecht, The Netherlands, 2008.

116. Lei, Z.; Bi, S.; Hu, B.; Yang, H. Combined magnetic and chemical covalent immobilization of pectinase on composites membranes improves stability and activity. Food Chem. 2007, 105, 889-896. 
117. Bayramoglu, G.; Yılmaz, M.; Şenel, A.U.; Arıca, M.Y. Preparation of nanofibrous polymer grafted magnetic poly(GMA-MMA)-g-MAA beads for immobilization of trypsin via adsorption. Biochem. Eng. J. 2008, 40, 262-274.

118. Wang, S.; Bao, H.; Yang, P.; Chen, G. Immobilization of trypsin in polyaniline-coated nano- $\mathrm{Fe}_{3} \mathrm{O}_{4} /$ carbon nanotube composite for protein digestion. Anal. Chim. Acta 2008, 612, 182-189.

119. Li, Y.; Xu, X.; Deng, C.; Yang, P.; Zhang, X. Immobilization of trypsin on superparamagnetic nanoparticles for rapid and effective proteolysis. J. Proteome Res. 2007, 6, 3849-3855.

120. Liu, J.; Lin, S.; Qi, D.; Deng, C.; Yang, P.; Zhang, X. On-chip enzymatic microreactor using trypsin-immobilized superparamagnetic nanoparticles for highly efficient proteolysis. J. Chromatogr. A 2007, 1176, 169-177.

121. Hong, J.; Gong, P.; Xu, D.; Dong, L.; Yao, S. Stabilization of alpha-chymotrypsin by covalent immobilization on amine-functionalized superparamagnetic nanogel. J. Biotechnol. 2007, 128, 597-605.

122. Munro, P.A.; Dunnil, P.; Lilly, M.D. Casein hydrolysis in stirred tank reactors using chymotrypsin immobilized on magnetic supports. Biotechnol. Bioeng. 2004, 23, 677-689.

123. Závišová, V.; Koneracká, M.; Tomašovičová, N.; Kopčanský, P.; Timko, M. Some Immobilization Modes of Biologically Active Substances to Fine Magnetic Particles. Z. Phys. Chem. 2006, 220, 241-250.

124. Xin, B.-J.; Si, S.-F.; Xing, G.-W. Protease immobilization on gamma- $\mathrm{Fe}_{2} \mathrm{O}_{3} / \mathrm{Fe}_{3} \mathrm{O}_{4}$ magnetic nanoparticles for the synthesis of oligopeptides in organic solvents. Chem. Asian J. 2010, 5, 1389-1394.

125. Chen, J.-P.; Su, D.-R. Latex particles with thermo-flocculation and magnetic properties for immobilization of $\alpha$-chymotrypsin. Biotechnol. Prog. 2001, 17, 369-375.

126. Yu, J.; Wang, C.; Hong, J.; Huang, J. Resolution of (D, L)-Phenylalanine in Biphasic System by $\alpha$-Chymotrypsin Immobilized on Superparamagnetic Nanogels. J. Macromol. Sci. Pure Appl. Chem. 2009, 46, 943-948.

127. Korecká, L.; Ježová, J.; Bílková, Z.; Beneš, M.; Horák, D.; Hradcová, O.; Slováková, M.; Viovy, J.-L. Magnetic enzyme reactors for isolation and study of heterogeneous glycoproteins. J. Magn. Magn. Mater. 2005, 293, 349-357.

128. Yoshino, T.; Nishimura, T.; Mori, T.; Suzuki, S.; Kambara, H.; Takeyama, H.; Matsunaga, T. Nano-sized bacterial magnetic particles displaying pyruvate phosphate dikinase for pyrosequencing. Biotechnol. Bioeng. 2009, 103, 130-137.

129. Garcia, J.; Zhang, Y.; Taylor, H.; Cespedes, O.; Webb, M.E.; Zhou, D. Multilayer enzyme-coupled magnetic nanoparticles as efficient, reusable biocatalysts and biosensors. Nanoscale 2011, 3, 3721-3730.

130. Qiu, J.; Peng, H.; Liang, R. Ferrocene-modified $\mathrm{Fe}_{3} \mathrm{O}_{4} @ \mathrm{SiO}_{2}$ magnetic nanoparticles as building blocks for construction of reagentless enzyme-based biosensors. Electrochem. Commun. 2007, 9 , 2734-2738.

131. Rossi, L.M.; Quach, A.D.; Rosenzweig, Z. Glucose oxidase-magnetite nanoparticle bioconjugate for glucose sensing. Anal. Bioanal. Chem. 2004, 380, 606-613.

132. Caruso, F.; Schuler, C. Enzyme Multilayers on Colloid Particles: Assembly, Stability, and Enzymatic Activity. Langmuir 2000, 16, 9595-9603. 
133. Yang, L.; Xiong, H.; Zhang, X.; Wang, S.; Zhang, X. Direct electrochemistry of glucose oxidase and biosensing for glucose based on boron-doped carbon-coated nickel modified electrode. Biosens. Bioelectron. 2011, 26, 3801-3805.

134. Ashtari, K.; Khajeh, K.; Fasihi, J.; Ashtari, P.; Ramazani, A.; Vali, H. Silica-encapsulated magnetic nanoparticles: Enzyme immobilization and cytotoxic study. Int. J. Biol. Macromol. 2012, 50, 1063-1069.

135. Sheng, J.; Zhang, L.; Lei, J.; Ju, H. Fabrication of tunable microreactor with enzyme modified magnetic nanoparticles for microfluidic electrochemical detection of glucose. Anal. Chim. Acta 2012, 709, 41-46.

136. Jeong, J.; Ha, T.H.; Chung, B.H. Enhanced reusability of hexa-arginine-tagged esterase immobilized on gold-coated magnetic nanoparticles. Anal. Chim. Acta. 2006, 569, 203-209.

137. Zeng, L.; Luo, K.; Gong, Y. Preparation and characterization of dendritic composite magnetic particles as a novel enzyme immobilization carrier. J. Mol. Catal. B-Enzym. 2006, 38, 24-30.

138. Li, G.Y.; Huang, K.L.; Jiang, Y.R.; Yang, D.L.; Ding, P. Preparation and characterization of Saccharomyces cerevisiae alcohol dehydrogenase immobilized on magnetic nanoparticles. Int. J. Biol. Macromol. 2008, 42, 405-412.

139. Kuroiwa, T.; Noguchi, Y.; Nakajima, M.; Sato, S.; Mukataka, S.; Ichikawa, S. Production of chitosan oligosaccharides using chitosanase immobilized on amylose-coated magnetic nanoparticles. Process Biochem. 2008, 43, 62-69.

140. Monaghan, R.; Eveleigh, D.; Tewari, R. Chitosanase, a novel enzyme. Nat. New Biol. 1973, 245, 78-80.

141. Zhang D.H.; Yuwen, L.X.; Xie, Y.L.; Li, W.; Li, X.B. Study on immobilization of lipase onto magnetic microspheres triacylglycerol lipase. J. Magn. Magn. Mater. 2009, 321, 252-258.

142. Keilin, D.; Mann, T. A Rapid Visual Test for Vitamin A Deficiency. Nature 1939, 143, 23.

143. Wang, F.; Guo, C.; Liu, H.-Z.; Liu, C.-Z. Immobilization of Pycnoporus sanguineus laccase by metal affinity adsorption on magnetic chelator particles. J. Chem. Technol. Biotechnol. 2008, 83, 97-104.

144. Çevik, E.; Şenel, M.; Abasiyanik, M.F. Immobilization of urease on copper chelated EC-Tri beads and reversible adsorption. Afr. J. Biotechnol. 2011, 10, 6590-6597.

145. Wang, W.; Wang, D.I.C.; Li, Z. Facile fabrication of recyclable and active nanobiocatalyst: Purification and immobilization of enzyme in one pot with Ni-NTA functionalized magnetic nanoparticle. Chem. Commun. 2011, 47, 8115-8117.

146. Choi, S.H.; Kim, H.S.; Lee, I.S.; Lee, E.Y. Functional expression and magnetic nanoparticle-based Immobilization of a protein-engineered marine fish epoxide hydrolase of Mugil cephalus for enantioselective hydrolysis of racemic styrene oxide. Biotechnol. Lett. 2010, 32, 1685-1691.

147. Zhang, R.Q.; Nakajima, H.; Soh, N.; Nakano, K.; Masadome, T.; Nagata, K. Sakamoto, K.; Imato, T. Sequential injection chemiluminescence immunoassay for nonionic surfactants by using magnetic microbeads. Anal. Chim. Acta 2007, 600, 105-113.

148. Nidumolu, B.G.; Urbina, M.C.; Hormes, J.; Kumar, C.S.; Monroe, W.T. Functionalization of Gold and Glass Surfaces with Magnetic Nanoparticles Using Biomolecular Interactions. Biotechnol. Prog. 2006, 22, 91-95. 
149. Cao, M.; Li, Z.; Wang, J.; Ge, W.; Yue, T.; Li, R. Food related applications of magnetic iron oxide nanoparticles: Enzyme immobilization, protein purification, and food analysis. Trends Food Sci. Technol. 2012, 27, 47-56.

150. Sun, J.; Su, Y.; Rao, S.; Yang, Y. Separation of lysozyme using superparamagnetic carboxymethyl chitosan nanoparticles. J. Chromatogr. B 2011, 879, 2194-2200.

151. Zhang, G.; Cao, Q.; Li, N.; Li, K.; Liu, F. Tris(hydroxymethyl) aminomethane-modified magnetic microspheres for rapid affinity purification of lysozyme. Talanta 2011, 83, 1515-1520.

152. Liao, M.; Chen, D. Fast and efficient adsorption/desorption of protein by a novel magnetic nano-adsorbent. Biotechnol. Lett. 2002, 24, 1913-1917.

153. Başar, N.; Uzun, L.; Güner, A.; Denizli, A. Lysozyme purification with dye-affinity beads under magnetic field. Int. J. Biol. Macromol. 2007, 41, 234-242.

154. Meyer, A.; Hansen, D.B.; Gomes, C.S.G.; Hobley, T.J.; Thomas, O.R.T.; Franzreb, M. Demonstration of a strategy for product purification by high-gradient magnetic fishing: Recovery of superoxide dismutase from unconditioned whey. Biotechnol. Progr. 2005, 21, 244-254.

155. Huang, S.; Liao, M.; Chen, D. Fast and efficient recovery of lipase by polyacrylic acid-coatedmagnetic nano-adsorbent with high activity retention. Sep. Sci. Technol. 2006, 51, 113-117.

156. Sahu, S.K.; Chakrabarty, A.; Bhattacharya, D.; Ghosh, S.K.; Pramanik, P. Single step surface modification of highly stable magnetic nanoparticles for purification of His-tag proteins. J. Nanopart. Res. 2011, 13, 2475-2484.

157. Chen, L.; Guo, C.; Guan, Y.; Liu, H. Isolation of lactoferrin from acid whey by magnetic affinity separation. Sep. Sci. Technol. 2007, 56, 168-174.

158. Ma, Z.; Liu, X.; Guan, Y.; Liu, H. Synthesis of magnetic silica nanospheres with metal ligands and application in affinity separation of proteins. Colloid Surf. A-Physicochem. Eng. Asp. 2006, 275, 87-91.

159. Cao, Y.; Tian, W.; Gao, S.; Yu, Y.; Yang, W.; Bai, G. Immobilization staphylococcal protein A on magnetic cellulose microspheres for IgG affinity purification. Artif. Cells Blood Substit. Biotechnol. 2007, 35, 467-480.

160. Ma, Z.; Liu, X.; Guan, Y.; Liu, H. Superparamagnetic silica nanoparticles with immobilized metal affinity ligands for protein adsorption. J. Magn. Magn. Mater. 2006, 301, 469-477.

161. Fang, W.; Chen, X.; Zheng, N. Superparamagnetic core-shell polymer particles for efficient purification of his-tagged proteins. J. Mater. Chem. 2010, 20, 8624-8630.

162. Xu, F.; Geiger, J.H.; Baker, G.L.; Bruening, M.L. Polymer Brush-Modified Magnetic Nanoparticles for His-Tagged Protein Purification. Langmuir 2011, 27, 3106-3112.

163. Shao, M.; Ning, F.; Zhao, J.; Wei, M.; Evans, D.G.; Duan, X. Preparation of $\mathrm{Fe}_{3} \mathrm{O}_{4} @ \mathrm{SiO}_{2} @$ Layered Double Hydroxide Core-Shell Microspheres for Magnetic Separation of Proteins. J. Am. Chem. Soc. 2012, 134, 1071-1077.

164. Hua, M.-Y.; Liu, H.-L.; Huang, C.-Y.; Wei, K.-C.; Yang, H.-W. Potential of magnetic nanoparticles for targeted drug delivery. Nanotechnol. Sci. Appl. 2012, 5, 73-86.

165. Kumar, S.; Jana, A.K.; Dhamija, I.; Singla, Y.; Maiti, M. Preparation, characterization and targeted delivery of serratiopeptidase immobilized on amino-functionalized magnetic nanoparticles. Eur. J. Pharm. Biopharm. 2013, 85, 413-426. 
166. Wang, X.; Yang, T.; Jiao, K. Electrochemical sensing the DNA damage in situ induced by a cathodic process based on $\mathrm{Fe} @ \mathrm{Fe}_{2} \mathrm{O}_{3}$ core-shell nanonecklace and Au nanoparticles mimicking metal toxicity pathways in vivo. Biosens. Bioelectron. 2009, 25, 668-673.

167. Qiu, J.D.; Peng, H.P.; Liang, R.P.; Xia, X.H. Facile preparation of magnetic core-shell $\mathrm{Fe}_{3} \mathrm{O}_{4} @ \mathrm{Au}$ nanoparticle/myoglobin biofilm for direct electrochemistry Biosens. Bioelectron. 2010, 25, 1447-1453.

168. Kaushik, A.; Khan, R.; Solanki, P.R.; Pandey, P.; Alam, J.; Ahmad, S.; Malhotra, B.D. Iron oxide nanoparticles-chitosan composite based glucose biosensor. Biosens. Bioelectron. 2008, 24, 676-683.

169. Weissleder, R. Molecular imaging in cancer. Science 2006, 312, 1168-1171.

170. Jun, Y.W.; Lee, J.H. Cheon, J. Chemical design of nanoparticle probes for high-performance magnetic resonance imaging. Angew. Chem. Int. Ed. 2008, 47, 5122-5135.

171. Wunderbaldinger, P.; Josephson, L.; Weissleder, R. Crosslinked iron oxides (CLIO): A new platform for the development of targeted MR contrast agents. Acad. Radiol. 2002, 9, S304-S306.

172. Speroni, F.; Elviri, L.; Careri, M.; Mangia, A. Magnetic particles functionalized with PAMAM-dendrimers and antibodies: A new system for an ELISA method able to detect Ara h3/4 peanut allergen in foods. Anal. Bioanal. Chem. 2010, 397, 3035-3042.

Sample Availability: Not available.

(C) 2014 by the authors; licensee MDPI, Basel, Switzerland. This article is an open access article distributed under the terms and conditions of the Creative Commons Attribution license (http://creativecommons.org/licenses/by/3.0/). 